\title{
Discovery of the Bank Vole (Myodes glareolus) on Ushant Island (Brittany, France)
}

\begin{tabular}{|c|c|}
\hline Journal: & Mammalia \\
\hline Manuscript ID & Draft \\
\hline Manuscript Type: & Short Note \\
\hline Date Submitted by the Author: & $\mathrm{n} / \mathrm{a}$ \\
\hline Complete List of Authors: & $\begin{array}{l}\text { Lorvelec, Olivier; ESE (Ecology and Ecosystem Health), INRA, Agrocampus } \\
\text { Ouest, } 35042 \\
\text { Rolland, Pascal; Groupe mammalogique breton (GMB), Maison de la } \\
\text { Rivière, } 29450 \\
\text { Le Quilliec, Patricia; ESE (Ecology and Ecosystem Health), INRA, } \\
\text { Agrocampus Ouest, } 35042 \\
\text { Quénot, François; Centre d'étude du milieu d'Ouessant (CEMO), Ar } \\
\text { Gouzoul, 29242 } \\
\text { Butet, Alain; Univ. Rennes, CNRS, ECOBIO (Écosystèmes, biodiversité, } \\
\text { évolution) - UMR 6553, } 35000\end{array}$ \\
\hline Classifications: & Ecology, Conservation \\
\hline Keywords: & Myodes glareolus, island, Ushant, Brittany, introduction \\
\hline
\end{tabular}



Butet

\title{
Discovery of the Bank Vole (Myodes glareolus) on Ushant Island (Brittany, France)
}

\author{
[Découverte du Campagnol roussâtre (Myodes glareolus) sur l'île d'Ouessant \\ (Bretagne, France)]
}

Running title: O. Lorvelec et al.: Bank Vole on Ushant Island

\begin{abstract}
Ecological monitoring of small mammals by trapping revealed the presence of the Bank Vole (Myodes glareolus) on Ushant Island (Brittany, France) in September 2017. It was the first report of the Bank Vole on this island. Comparison with prior monitoring efforts and an analysis of several batches of Barn Owl pellets allowed us to conclude that arrival on the island is recent, in any case sometime after 1995, and dating from the beginning of 2017 at the latest. It will be necessary to verify if the current population, still incompletely distributed into suitable habitats of the island, are maintaining themselves on a long term basis.
\end{abstract}

Keywords: Myodes glareolus, island, Ushant, Brittany, introduction

In the Atlas of Brittany's Mammals, Rolland and Hamon (2015) report the presence of four species of Rodents (Long-tailed Field Mouse, House Mouse, Roof Rat, and Brown Rat), only one Lagomorph (European Rabbit), and two "Insectivores" (Lesser White-toothed Shrew and West European Hedgehog) on Ushant Island (Department of Finistère, Brittany, France, $1558 \mathrm{ha}$, latitude 48.461, longitude -5.080). During ecological monitoring of small mammals conducted from 25 to 29 September 2017 on this island, as well as on its satellite, Keller Island (28 ha), and most of its peripheral rocky islets with perennial terrestrial vegetation (i.e., Enez Kadoran, Ledenez Arlan, Enez ar Bougeviou Glas, Youc'h Arland, Roc'h Nel, Enez Penn ar Roc'h, Youc'h Korz, Youc'h Kreiz, and Youc'h Meur), we detected the presence of the Bank Vole on the main island.

The Bank Vole, Myodes glareolus (Schreber, 1780), is a Rodent belonging to the subfamily Arvicolinae within the family Cricetidae. In the past, Evotomys glareolus then Clethrionomys glareolus were names often used for this species, but Evotomys and Clethrionomys are currently in the list of synonyms of the genus name Myodes. A discussion about these complex nomenclatural issues is available especially in Carleton and Musser (2005) and

\footnotetext{
"Corresponding author: Olivier Lorvelec, ESE (Ecology and Ecosystem Health), INRA, Agrocampus Ouest, 35042 Rennes, France, e-mail: olivier.lorvelec@inra.fr

Pascal Rolland: Groupe mammalogique Breton, GMB, Maison de la Rivière, 29450 Sizun, France, email: pjr.rolland@laposte.net

Patricia Le Quilliec: ESE (Ecology and Ecosystem Health), INRA, Agrocampus Ouest, 35042

Rennes, France, e-mail : patricia.le-quilliec@inra.fr

François Quénot: Centre d'étude du milieu d'Ouessant, CEMO, Ar Gouzoul, 29242 Ouessant, France, e-mail: fanch.quenot@gmail.com

Alain Butet: Univ. Rennes, CNRS, ECOBIO (Écosystèmes, biodiversité, évolution) - UMR 6553, 35000 Rennes, France, e-mail: alain.butet@univ-rennes1.fr
} 
Carleton et al. (2014). Formerly, because of a significant morphological variability, authors defined tens of subspecies but, in 2005, Carleton and Musser recognize none as valid.

Within the Western Palearctic, its distribution area extends from Lake Baikal to north of the Iberian Peninsula, Great Britain and south-west Ireland, where its presence is the result of an introduction. To the north, its range extends very clearly beyond the Arctic Circle in the Scandinavian Peninsula. To the south, it extends to the Turkish Black Sea coast, northern Greece and the southern Italian Peninsula (Spitzenberger 1999, Carleton and Musser 2005, Hutterer et al. 2016). In France, the Bank Vole is present everywhere with the exception of the Mediterranean coast and Corsica (Saint Girons 1984). In particular, it is present everywhere in Brittany (Department of Loire-Atlantique included, Verger 2015). This species may find favourable habitats in different woodland or hedgerow habitats with relatively high humidity (Spitzenberger 1999, Le Louarn et al. 2003). However, when Voles of the genus Microtus are absent, as it is the case in Belle-Île (see below), the Bank Vole is able to colonize open fields (Saint Girons and Beaucournu 1970). In France, it has no legal status. Anonymous (2017) assessed the risk of extinction of the species as "Least Concern".

Until the end of the 20th century, Belle-Ile (Department of Morbihan, 8563 ha) was the only French Island where the presence of the Bank Vole was known (Heim de Balsac 1940, Saint Girons 1984). However, this species was also recorded (Miller 1908, Saint Girons and Beaucournu 1970) on the Channel Island of Jersey (11820 ha). These two islands host individuals that are darker and larger than individuals of close continental areas (Saint Girons and Beaucournu 1970, Saint Girons 1973). Because of their insularity and special colouration, authors originally defined these morphs as insular endemic taxa: Clethrionomys glareolus insulæ-bellæ Heim de Balsac, 1940 for Belle-île, Evotomys cæsarius Miller, 1908 for Jersey Island. These names are currently included in the list of synonyms of Myodes glareolus, e.g., in Carleton and Musser (2005). That seems consistent with the fact that isolation of Ponant and Channel Islands, which are Holocene Islands, is too recent to allow speciation or sub-speciation. In addition, we do not know if the Bank Vole was already present in these territories at the time of their isolation, or if its presence results from an old introduction.

In the 21st century, authors reported the presence of the Bank Vole on three new Brittany Islands (Rolland and Hamon 2015). On "Île des Morts" (Roadstead of Brest, Department of Finistère, $7 \mathrm{ha}$ ), the presence of an individual was mentioned during the 2005 Brown rat (Rattus norvegicus) eradication campaign, whereas the species was not found during a 2004 ecological monitoring of small mammals, which was based on 125 nights $x$ traps (Louis Dutouquet, pers. comm., February 2018). However, because of a lack of information, this mention is an unconfirmed observation that necessitates validation with new monitoring. The first surveys on Dumet Island (Department of Loire-Atlantique, 7,6 ha), probably based in part on Barn Owl pellet analysis, did not mention the presence of the Bank Vole (BaudouinBodin 1976, 1982, Saint Girons and Nicolau-Guillaumet 1987, Saint Girons 1988). On December 7, 2013, live individuals and skulls in Barn Owl (Tyto alba) pellets were reported (Montfort 2014, Rolland and Hamon 2015). During a survey conducted by INRA parasitologists and one of the authors $(A B)$ in October 2016, the species was again observed. Therefore, historical data suggests an introduction of the Bank Vole on Dumet Island sometime after the 1980s, although doubt remains because of a lack of information relating to samplings and their completeness. In this regard, (i) we know that a shrew lived on Dumet Islands in 1972 while the Bank Vole was there unknown (Baudouin-Bodin 1976) and (ii) that pellets collected in January 1973 had been sent to the Natural History Museum of Nantes (Pierre Davoust, pers. comm., 2009). On Hœdic Island (Department of Morbihan, 208 ha), a dried corpse of Bank Vole was discovered near the harbour on June 18, 2016 (Rolland, in press), but subsequent trappings could not confirm the presence of this species. We do not know if this specimen was introduced, via the harbour, alive or already dead, 
which seems most likely to us, or whether this specimen indicates the presence of an established population. We only know that on Hœdic and Houat (291 ha) Islands, the Bank Vole was not mentioned in a 2002 ecological monitoring of small mammals by trapping, carried by the French Coastal Protection Agency (CELRL, Louis Dutouquet, pers. comm., February 2018).

On Ushant Island, where the Bank Vole was discovered on September $26^{\text {th }}, 2017$, a total of 299 traps (1190 trap x nights) were positioned to sample the primary ecological habitats of the island. For this survey we used INRA live-traps (Aubry 1950), solid aluminium boxes of dimensions $160 \times 45 \times 45 \mathrm{~mm}$ for captures of small mammals less than $40 \mathrm{~g}$. A plastic dorm box, containing an absorbent paper sheet and the bait (a mixture of peanut paste and oat flakes) was added to traps in order to improve trapping efficiency and reduce mortality of individuals during capture. We captured voles on the southwest, central and northeast portions of the island along a two kilometers wide strip linking Lampaul village to the sea lighthouse of Stiff. Captures occurred inside or at the borders of dense intermediate plant associations that are actually becoming dominant on the island (Loncle and Bioret 2010): ferns and bramble bushes, thickets of gorse (Ulex europaeus) and willow copses. Among the 27 individuals caught, 10 were autopsied at the laboratory and 5 skulls were examined to confirm species identification.

To deduce whether the species' presence might be the result of a possible recent introduction in connection with the arrivals of materials by boat (firewood, fodder, etc.), we conducted a retrospective analysis of past sampling campaigns and more recently collected Barn Owl pellets that were available for this island.

A first inventory of mammals living on the main Ushant Island was conducted between 1992 and 1995 (Howell and Bioret 1995, Pascal et al. 2002). The trapping design included up to 86 trapping plots per year, featuring two small mammal trap models (INRA and Sherman). This trapping campaign was performed in all habitats of the eastern part of the island, equal to a third of the island's total area. Despite this important trapping effort, no Bank Vole was caught and no signs of its presence were found as well. It is unlikely that the species went unnoticed during this first trapping period. Nevertheless, it should be noted that out of the whole trapping stations used at this period, only four were localized in optimal habitats of this species and situated close to our trapping plots that captured Bank Voles in 2017.

Although predation rate of the Bank Vole by Barn Owl is lower than for most other small rodent species (Saint Girons 1973), this Vole is systematically detected in rejection pellets when populations are well established locally. A pair of Barn Owls settled on Ushant Island at the end of the 2000s in the central part of the island. Pellets found close to the nest after fledging in 2010, 2011, 2015 and 2017 were collected and analyzed by two of the authors (FQ and PR). Pellets collected in 2010 and 2011 contained 277 mammals, and those from 2015 contained 278. Bank Voles were not detected among prey items in these years. In September 2017, collected pellet batches were bulky, but lower strata were highly degraded by moisture. Only 30 pellets from 2017 were sufficiently well formed to permit analysis, but nevertheless revealed 152 mammal prey items, including 7 Bank Voles (4.6\% of total prey). A rapid examination of the most degraded material allowed identification of two more Bank Voles that were probably predated earlier in 2017 or at the end of 2016 . It is important to note that the percentage of $4.6 \%$ in the batch of 2017 is high for this rodent species, and higher than what is generally found on the continent (3\% in Finistère, $2.9 \%$ in Brittany, Verger 2015). Such comparisons are nevertheless to be taken with caution given the diversity of situations according to the sites and periods. This suggests that the Bank Vole is likely well established on the island, at least in places corresponding to hunting areas of the Barn Owl pair. 
Both pellet analysis and results of censuses, more than 20 years apart, argue for a recent arrival of the Bank Vole, which probably occurred at the end of 2016 or early 2017 . We cannot exclude the possibility that the Bank Vole may have been introduced some years before but with a distribution and a density too low to appear in owl pellets. Furthermore, this rodent, as with other vole species, displays high numerical fluctuations that might also explain its absence in small pellet collections. Only a continuous intensive monitoring through pellet analysis, would have helped to ascertain a more ancient presence posterior to trapping campaigns of the 1990s. The erratic presence of the Barn Owl on Ushant Island before 2010 did not permit such research. In September 2017, during the most recent trapping, the Bank Vole was not detected in numerous sampled habitats we judged to be good, suggesting that colonization of the island is still in progress.

To conclude, we may consider the Bank Vole as a new species of the mammal community on the main Ushant Island. Its presence has been confirmed in 2017 by both trapping and Barn Owl pellet analysis. The arrival of this small rodent is obviously posterior to 1995 and is not later than early 2017 . We will have to verify if this population, still actively colonizing bushy habitats of the island, is likely to maintain itself over time. Likewise, future work should examine phenotypic drift resulting from a founding effect. In this regard, it should be noted that the 10 autopsied individuals displayed a yellowish color of the belly in contrast to the typical greyish colors of continental individuals. However, weakness of our sample calls for caution and further observations will be necessary to validate difference in the coloring of the animals of the island to those of the near continent.

Acknowledgements: Run by the French National Institute for Agronomic Research (INRA), the ecological monitoring of small mammals living on Brittany Islands (2014-2018) was validated in 2014 by the scientific council of the Brittany insular nature reserves. The regional ethics committee concluded in 2013 that this project does not present any problem in terms of animal experimentation. Realization of this multi-partner project was possible thanks to collaboration and logistic support from managers of sampled natural areas.

Here we thank all participants of the project relating to Ushant Island, its peripheral rocky islets and Keller Island that took place in September 2017:

Institutions: Participants

CEMO (ONG): François Quénot

UMR 6553 ECOBIO (CNRS, Univ. Rennes 1): Alain Butet

UMR 5199 PACEA (CNRS, Univ. Bordeaux 1): Arnaud Lenoble

GMB (ONG): Josselin Boireau and Pascal Rolland

UMR 1300 BioEpAR (INRA, ONIRIS): Albert Agoulon, Olivier Plantard, and Yann Quenet

UMR 0985 ESE (INRA, Agrocampus Ouest): Damien Fourcy, Patricia Le Quilliec, and Olivier Lorvelec

LPO, RNN Sept-Îles: Armel Deniau and Julie Grousseau

UMR 7204 CESCO (MNHN, CNRS, Univ. Paris 6): Jean-Louis Chapuis

UMR 7205 ISYEB (MNHN, Univ. Paris 6, EPHE): Vivien Louppe

UMS 2006 PATRINAT (MNHN, AFB, CNRS): Benoît Pisanu

ONCFS: BMI Bretagne - Pays de la Loire: Arnaud Le Cras

ONCFS: Finistère: Jacques Bajul and Yann Goasguen

AFB: PNMI: Antoine Besnier, David Bourles, Jean-Philippe Coeffet, Stéphane Dixneuf, and Yannis Turpin

PNRA: Cédric Caïn, Olivier Jonquet, Agathe Larzillière, and Robert Le Goff

Volunteers: Cédric Barbeyron, Bruno Ferré, Loïc Monmasson, and François Siorat.

Translation of French acronyms. CEMO: Study Center for the Environment of Ushant Island. ONG: nongovernmental organization. UMR: joint research unit. ECOBIO: Ecosystems, Biodiversity, Evolution. CNRS: National Center for Scientific Research. PACEA: From Prehistory to the Present: Culture, Environment and Anthropology. GMB: Breton Mammalogical Group. BioEPAR: Biology, Epidemiology and Risk Analysis in animal health. INRA: National Institute for Agronomic Research. ONIRIS: Nantes-Atlantic National College of Veterinary 
Medicine, Food Science and Engineering. ESE: Ecology and Ecosystems Health. Agrocampus Ouest: Institute for life, food and horticultural sciences and landscaping. LPO: Bird Protection League (French BirdLife partner). RNN Sept-Îles: National Nature Reserve of the Sept-Îles. CESCO: Centre for Ecology and Conservation Sciences. MNHN: National Museum of Natural History. ISYEB: Institute of Systematics, Evolution, Biodiversity. EPHE: École Pratique des Hautes Études. PATRINAT: Natural Heritage. AFB: French Agency for Biodiversity. ONCFS: National Hunting and Wildlife Agency. BMI: Mobile Intervention Brigade. Bretagne - Pays de la Loire: two administrative regions. Finistère: a county. PNMI: Iroise Marine Natural Park. PNRA: Armorica Regional Natural Park.

The Prefecture of Finistère and the French Coastal Protection Agency (CELRL) have authorized us to work (i.e., landing, trapping, and sampling small mammals specimens, according to skills of each institution). Owners of Keller Island have allowed us to work on their island. We informed the village council of Ushant and the Naturalist Association of Ushant (ANO) about project evolution. Managers of Iroise Sea insular natural environments (i.e., PNRA, PNMI, ONCFS Finistère, and CEMO) have run study with INRA. PNRA, PNMI, and CEMO largely funded study, and we carried out trapping with INRA material. PNMI and ONCFS Finistère made available their maritime logistics, including two boats with crews, which allowed us landing on rocky islets and Keller Island. We also thank Fred Bioret (University of Western Brittany - UBO) for information relating to the 1992-1995 ecological monitoring, Louis Dutouquet (Litto study office, coastal environment and island heritage) for data about various islands (see text), Nicolas Mothay (CELRL) for provision of documents, as well as Olivier Penard (Council of Loire-Atlantique) and Didier Montfort (French Society for Study and Protection of Mammals - SFEPM, Loire-Atlantique) for information on Dumet Island. Finally, we thank Scott McCairns (INRA ESE), who corrected English language.

\section{References}

Anonymous 2017. La Liste rouge des espèces menacées en France. Mammifères de France métropolitaine. French Committee of the International union for conservation of nature, Muséum national d'Histoire naturelle, Société française pour l'étude et la protection des mammifères, Office national de la chasse et de la faune sauvage, Paris, pp. 16.

Aubry, J. (1950). Deux pièges pour la capture de petits rongeurs vivants. Mammalia 14(4): 174-177.

Baudouin-Bodin, J. 1976. Sur l'importance d'une protection totale de l'île Dumet. Proceedings of the 97th "Congrès National des Sociétés Savantes", Nantes, 1972, "Section des Sciences", Tome 4, pp. 31-36.

Baudouin-Bodin, J. 1982. Contribution à l'étude de la flore de l'île Dumet. Ses modifications. Son évolution. B. Soc. Sc. Nat. de l'Ouest de la France, Nouvelle Série 4(4): 180-196.

Carleton, M.D., Gardner, A.L., Pavlinov, I.Y., and Musser, G.G. (2014). The valid generic name for red-backed voles (Muroidea: Cricetidae: Arvicolinae): restatement of the case for Myodes Pallas, 1811. J. Mammal. 95(5): 943-959.

Carleton, M.D. and Musser, G.G. 2005. Order Rodentia. In: (D.E. Wilson and D.A.M. Reeder, eds). Mammals Species of the World: A Taxonomic and Geographic Reference. Third Edition. Volume 2. The Johns Hopkins University Press, Baltimore, Md., pp. 745-1600.

Heim de Balzac, H. (1940). Zoologie. Faune mammalienne des îles littorales atlantiques. C.R. Acad. Sc. de Paris 211 (Série III, Session 16 September 1940): 212-214.

Howell, J.A. and Bioret, F. 1995. Comparative Ecosystem Study Between two Coastal MAB Biosphere Reserves, France and United States. Biosphere Reserve comparison. In: (R.M. Lin, ed) Sustainable Society and Protected Areas. The George Wright Society, Hancock, Mich., 1995. Contributed papers of the $8^{\text {th }}$ Conference on research and resource management in parks and on public lands, 17-21 April 1995, Portland, Ore., pp. 81-92

Hutterer, R., Kryštufek, B., Yigit, N., Mitsain, G., Palomo, L.J., Henttonen, H., Vohralík, V., Zagorodnyuk, I., Juškaitis, R., Meinig, H., and Bertolino, S. (2016). Myodes glareolus (errata version published in 2017). The IUCN Red List of Threatened Species 2016: e.T4973A115070929. http://dx.doi.org/10.2305/IUCN.UK.2016-3.RLTS.T4973A22372716.en. Downloaded on 22 January 2018. 
Le Louarn, H., Quéré, J.P., and Butet, A. 2003. Les Rongeurs de France. Faunistique et Biologie. $2^{\mathrm{e}}$ Édition Revue et Augmentée. INRA, Paris, $256 \mathrm{pp}$.

Loncle, N. and Bioret, F. 2010. Cartographie de la végétation de l'île d'Ouessant. Les Cahiers du CEMO, 3, pp. 26, carte (phytosociological units in 2006). Centre d'étude du milieu d'Ouessant (CEMO), Ouessant, Bretagne, France.

Miller, G.S. 1908. Eighteen new European voles. Ann. Mag. Nat. Hist., including Zoology, Botany, and Geology 1 (Serie 8, Number 2, February 1908): 194-206.

Montfort, D. 2014. Micromammifères de l'île Dumet. Mammi ’Breizh, Newsletter of the Groupe mammalogique Breton (GMB) 27 (September 2014): 7.

Pascal, M., Siorat, F., Brithmer, R., Culioli, J.-M., and Delloue, X. 2002. Au péril de la biodiversité. Penn ar Bed, Journal of the Association Bretagne vivante 184-185: 80-86.

Rolland, P. (in press). Les mammifères terrestres de Houat et Hœdic. Melvan, La Revue des Deux Îles.

Rolland, P. and Hamon, P. 2015. Mammifères insulaires en Bretagne. In: (F. Simmonet, coordonnateur) Atlas des Mammifères de Bretagne. Groupe mammalogique Breton (GMB), Sizun, Bretagne, France, Locus Solus Edition, Châteaulin, Bretagne, France, pp. 35-37.

Saint Girons, M.-C. 1973. Genre Clethrionomys Tilesius, 1850. Clethrionomys glareolus (Schreber, 1780), le Campagnol roussâtre. In: (M.C. Saint Girons) Les Mammifères de France et du Benelux (Faune Marine Exceptée). Doin, Paris, pp. 314-321.

Saint Girons, M.-C. 1984. Le Campagnol roussâtre. Clethrionomys glareolus. In: (A. Fayard, coordinator) Atlas des Mammifères Sauvages de France. Société française pour l'étude et la protection des mammifères, Paris, pp. 160-161.

Saint Girons, M.-C. 1988. Le Campagnol roussâtre, Clethrionomys glareolus. In: (M.-C. Saint Girons, T. Lodé, and P. Nicolau-Guillaumet) Atlas des Mammifères Terrestres de Loire-Atlantique. Muséum national d'Histoire naturelle, Inventaires de faune et de flore, Fascicule 50, Ministère de l'environnement, Secrétariat de la faune et de la flore, Paris, pp. 70-71.

Saint Girons, M.-C. and Beaucournu, J.C. 1970. Notes sur les mammifères de France. X. Le Campagnol roussâtre de Belle Isle (Morbihan), Clethrionomys glareolus insulaebellae Heim de Balsac, 1940. Comparaison avec une population continentale proche, Clethrionomys glareolus (Schreber, 1790) de Puceul (Loire-Atlantique). Mammalia 34: 617-621.

Saint Girons, M.-C. and Nicolau-Guillaumet, P. 1987. Les phénomènes d'insularité dans les îles du Ponant (France). Mammifères et oiseaux. B. Soc. Zool. Fr. 112(1-2): 61-79.

Schreber, J.C.D. von 1778-1792. Die Säugthiere in Abbildungen nach der Natur mit Beschreibungen. Bierter Theil [Tome 4]. Das Stachelthier. Die Savie. Der Biber. Die Maus. Das Murmelthier. Das Eichhorn. Der Schläfer. Der Springer. Der Hase. Der Klippschliefer. W. Walther, Erlangen, Deutschland [see Sherborn (1891) for dates of publication of the various issues; pages 651-682, containing definition of Mus glareolus page 680, from 1780].

Sherborn, C.D. 1891. On the dates of the parts, plates, and text of Schreber's 'Säugthiere'. Proc. of the general meetings for scientific business of the Zool. Soc. Lond. 1891: 587-592.

Spitzenberger, F. 1999. Clethrionomys glareolus (Schreber, 1780). In: (A.J. Mitchell-Jones, G. Amori, W. Bogdanowicz, B. Kryštufek, P.J.H. Reijnders, F. Spitzenberger, M. Stubbe, J.B.M. Thissen, V. Vohralík, and J. Zima, eds). The Atlas of European Mammals. Academic Press, London, San Diego, Calif., pp. 212-213.

Verger, J. 2015. Campagnol roussâtre. Myodes glareolus. Muenn arrous. In: F. Simmonet, coordinator) Atlas des Mammifères de Bretagne. Groupe mammalogique Breton (GMB), Sizun, Bretagne, France, Locus Solus Edition, Châteaulin, Bretagne, France, pp. 234-235. 